Article

\title{
Addition of K22 Converts Spider Venom Peptide Pme2a from an Activator to an Inhibitor of Nav1.7
}

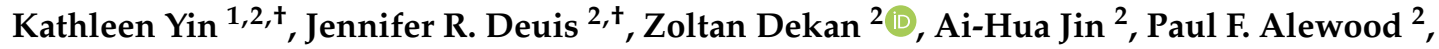 \\ Glenn F. King ${ }^{2} \mathbb{D}$, Volker Herzig ${ }^{2,3, * \mathbb{D}}$ and Irina Vetter $2,4, * \mathbb{D}$ \\ 1 Centre for Health Informatics, Australian Institute of Health Innovation, Macquarie University, North Ryde, \\ NSW 2109, Australia; kathleen.yin@mq.edu.au \\ 2 Institute for Molecular Bioscience, The University of Queensland, St. Lucia, QLD 4072, Australia; \\ j.deuis@uq.edu.au (J.R.D.); z.dekan@imb.uq.edu.au (Z.D.); a.jin@imb.uq.edu.au (A-H.J.); \\ p.alewood@imb.uq.edu.au (P.F.A.); glenn.king@imb.uq.edu.au (G.F.K.) \\ 3 School of Science \& Engineering, University of the Sunshine Coast, Sippy Downs, QLD 4556, Australia \\ 4 School of Pharmacy, The University of Queensland, Woolloongabba, QLD 4102, Australia \\ * Correspondence: vherzig@usc.edu.au (V.H.); i.vetter@uq.edu.au (I.V.); \\ Tel.: +61-7-5456-5382 (V.H.); +61-7-3346-2660 (I.V.) \\ + These authors contributed equally to this work.
}

Received: 22 January 2020; Accepted: 17 February 2020; Published: 19 February 2020

check for updates

\begin{abstract}
Spider venom is a novel source of disulfide-rich peptides with potent and selective activity at voltage-gated sodium channels $\left(\mathrm{Na}_{\mathrm{V}}\right)$. Here, we describe the discovery of $\mu$-theraphotoxin-Pme1a and $\mu / \delta$-theraphotoxin-Pme2a, two novel peptides from the venom of the Gooty Ornamental tarantula Poecilotheria metallica that modulate $\mathrm{Na}_{\mathrm{V}}$ channels. Pmela is a 35 residue peptide that inhibits $\mathrm{Na}_{\mathrm{V}} 1.7$ peak current $\left(\mathrm{IC}_{50} 334 \pm 114 \mathrm{nM}\right.$ ) and shifts the voltage dependence of activation to more depolarised membrane potentials $\left(\mathrm{V}_{1 / 2}\right.$ activation: $\left.\Delta=+11.6 \mathrm{mV}\right)$. Pme2a is a 33 residue peptide that delays fast inactivation and inhibits $\mathrm{Na}_{V} 1.7$ peak current $\left(\mathrm{EC}_{50}>10 \mu \mathrm{M}\right)$. Synthesis of a $[+22 \mathrm{~K}] \mathrm{Pme} 2 \mathrm{a}$ analogue increased potency at $\mathrm{Na}_{\mathrm{V}} 1.7\left(\mathrm{IC}_{50} 5.6 \pm 1.1 \mu \mathrm{M}\right)$ and removed the effect of the native peptide on fast inactivation, indicating that a lysine at position 22 (Pme2a numbering) is important for inhibitory activity. Results from this study may be used to guide the rational design of spider venom-derived peptides with improved potency and selectivity at $\mathrm{Na}_{\mathrm{V}}$ channels in the future.
\end{abstract}

Keywords: sodium channel; $\mathrm{Na}_{\mathrm{V}} 1.7 ; \mathrm{Na}_{\mathrm{V}} 1.8$; venom; spider; peptide

\section{Introduction}

Voltage-gated sodium channels $\left(\mathrm{Na}_{\mathrm{V}}\right)$ are pore-forming transmembrane proteins that regulate the influx of $\mathrm{Na}^{+}$ions across excitable cell membranes, making them essential for the initiation and propagation of action potentials. In humans, nine different subtypes have been described ( $\left.\mathrm{Na}_{\mathrm{V}} 1.1-1.9\right)$, each with unique biophysical properties and tissue-specific expression profiles [1]. Several subtypes, including $\mathrm{Na}_{\mathrm{V}} 1.7$ and $\mathrm{Na}_{\mathrm{V}} 1.8$, are highly expressed in peripheral sensory neurons and are therefore critical for somatosensation and nociception.

$\mathrm{Na}_{V} 1.7$ and $\mathrm{Na}_{V} 1.8$ are almost exclusively expressed in the peripheral nervous system, with preferential expression in small-diameter unmyelinated nociceptive or "pain-sensing" neurons [2-4]. In humans, loss-of-function mutations in $S C N 9 A$, the gene encoding $\mathrm{Na}_{\mathrm{V}} 1.7$, leads to congenital insensitivity to pain, while several gain-of-function mutations in SCN9A and SCN10A (the gene encoding $\mathrm{Na}_{\mathrm{V}}$ 1.8) are associated with painful peripheral neuropathies [5-7]. This is consistent with studies in rodents, whereby knockout of $S c n 9 a$ or $S c n 10 a$ leads to deficits in mechanical, thermal and inflammatory pain $[8,9]$, making both $\mathrm{Na}_{\mathrm{V}} 1.7$ and $\mathrm{Na}_{\mathrm{V}} 1.8$ promising therapeutic targets of interest for the treatment of pain. 
While many small-molecule $\mathrm{Na}_{V}$ inhibitors are used in the clinic, non-selective activity over other $\mathrm{Na}_{V}$ subtypes, including the central isoforms $\mathrm{Na}_{V} 1.1$ and $\mathrm{Na}_{\mathrm{V}} 1.2$ and the cardiac specific isoform $\mathrm{Na}_{V} 1.5[10,11]$, limits their widespread use as analgesics. Therefore, there has been a push to develop novel $\mathrm{Na}_{\mathrm{V}}$ inhibitors with improved subtype selectivity that target the less conserved voltage-sensing domains of the channel [12]. One source of novel $\mathrm{Na}_{\mathrm{V}}$ modulators is venoms from spiders, cone snails and scorpions, from which many peptides with exquisite Nav subtype selectivity have been described $[13,14]$. However, compared to tetrodotoxin (TTX)-sensitive $\mathrm{Na}_{\mathrm{V}}$ subtypes, relatively few venom-derived peptides with sub-micromolar potency at $\mathrm{Na}_{\mathrm{V}} 1.8$ have been characterised [15].

Therefore, the aim of this study was to use a high-throughput screen at $\mathrm{Na}_{\mathrm{V}} 1.8$ to identify novel bioactives from spider venom. Here, we describe the isolation and characterisation of two novel peptides from the Gooty Ornamental tarantula Poecilotheria metallica that modulate sodium channels.

\section{Experimental Section}

\subsection{Cell Culture}

Human Embryonic Kidney (HEK) 293 cells stably expressing human Na $1.7 / \beta 1$ (SB Drug Discovery, Glasgow, UK) were cultured in Minimum Essential Medium (MEM) supplemented with $10 \%$ fetal bovine serum (FBS), $2 \mathrm{mM} \mathrm{L}$-glutamine, and the selection antibiotics G-418 (0.6 mg/mL) and blasticidin $(4 \mu \mathrm{g} / \mathrm{mL})$, as recommended by the manufacturer. Chinese Hamster Ovary (CHO) cells stably expressing human $\mathrm{Na}_{\mathrm{V}} 1.8 / \beta 3$ in a tetracycline-inducible system (ChanTest, Cleveland, $\mathrm{OH}$, USA) were cultured in MEM supplemented with 10\% FBS and 2 mM L-glutamine. Expression of $\mathrm{hNa}_{\mathrm{V}} 1.8$ was induced by the addition of tetracycline $(1 \mu \mathrm{g} / \mathrm{mL})$ for $48-72 \mathrm{~h}$ prior to assays. HEK293 cells stably expressing rat transient receptor potential vanilloid 1 (TRPV1) were cultured in Dulbecco's Modified Eagle Medium (DMEM) containing 10\% FBS under selection with hygromycin B $(100 \mu \mathrm{g} / \mathrm{mL})$, generated as previously described [16]. Cells were grown in an incubator at $37{ }^{\circ} \mathrm{C}$ with $5 \% \mathrm{CO}_{2}$ and passaged every 3-4 days (at 70\%-80\% confluency) using TrypLE Express (Thermo Fisher Scientific, Scoresby, VIC, Australia).

\subsection{Venom Collection}

Venom of female $P$. metallica spiders was extracted by weak electrical stimulation as previously described [17] and dried and stored at $-20^{\circ} \mathrm{C}$, before being pooled and redissolved in milliQ water for further analysis.

\subsection{Membrane Potential Assay at $\mathrm{Na}_{V} 1.8$}

$\mathrm{CHO}$ cells stably expressing $\mathrm{hNa}_{\mathrm{V}} 1.8 / \beta 3$ were plated $48 \mathrm{~h}$ before the assay on 384 -well black-walled imaging plates coated with CellBIND (Corning, MA, USA) at a density of 10,000-15,000 cells/well and loaded with red membrane potential dye (Molecular Devices, Sunnyvale, CA, USA) plus TTX (1 $\mu$ M) diluted in physiological salt solution (PSS; $140 \mathrm{mM} \mathrm{NaCl}, 11.5 \mathrm{mM}$ glucose, $5.9 \mathrm{mM} \mathrm{KCl}, 1.4 \mathrm{mM}$ $\mathrm{MgCl}_{2}, 1.2 \mathrm{mM} \mathrm{NaH}_{2} \mathrm{PO}_{4}, 5 \mathrm{mM} \mathrm{NaHCO}, 1.8 \mathrm{mM} \mathrm{CaCl}_{2}, 10 \mathrm{mM} \mathrm{HEPES}$ ) and incubated for $30 \mathrm{~min}$ at $37^{\circ} \mathrm{C}$. Crude dried venom $(10 \mu \mathrm{g} /$ well) was diluted in PSS with $0.1 \%$ bovine serum albumin (BSA) and added using the FLIPR ${ }^{\text {TETRA }}$ (Molecular Devices) and incubated for 5 min before activation of $\mathrm{Na}_{\mathrm{V}} 1.8$ by addition of deltamethrin $(150 \mu \mathrm{M})$. Changes in membrane potential were assessed using the FLIPR ${ }^{\text {TETRA }}$ (excitation, 515-545 nm; emission, 565-625 nm) every $2 \mathrm{~s}$ for 25 min after adding the agonist. To quantify the activity of crude venom at $\mathrm{Na}_{V} 1.8$, the area under the curve (AUC) after the addition of deltamethrin was computed using ScreenWorks (Molecular Devices, Version 3.2.0.14).

\subsection{Isolation of Pme1a and Pme2a}

Crude $P$. metallica venom ( $1 \mathrm{mg}$ dried mass) was dissolved in 5\% acetonitrile (ACN)/0.1\% trifluoroacetic acid (TFA) and loaded onto an analytical $\mathrm{C}_{18}$ Reversed-Phase (RP) High-Pressure Liquid 
Chromatography (HPLC) column (Vydac $4.6 \times 250 \mathrm{~mm}, 5 \mu \mathrm{m}$; Grace, Columbia, MD, USA) attached to an UltiMate 3000 HPLC system (Dionex, Sunnyvale, CA, USA). Venom fractions were collected in $1 \mathrm{~min}$ intervals eluting at a flow rate of $0.7 \mathrm{~mL} / \mathrm{min}$ with solvent $\mathrm{A}\left(0.1 \%\right.$ formic acid in $\left.\mathrm{H}_{2} \mathrm{O}\right)$ and solvent $\mathrm{B}\left(90 \% \mathrm{ACN}, 0.1 \%\right.$ formic acid in $\left.\mathrm{H}_{2} \mathrm{O}\right)$ using the gradient: $5 \%$ solvent $\mathrm{B}$ over $5 \mathrm{~min}$, followed by $5 \%-50 \%$ solvent $B$ over $45 \mathrm{~min}$ followed by $50 \%-100 \%$ solvent $B$ over $25 \mathrm{~min}$.

Venom fractions were assessed for activity at $\mathrm{hNa} \mathrm{V}_{\mathrm{V}} 1.8$ using the FLIPR ${ }^{\mathrm{TETRA}}$ membrane potential assay as described above. The active fraction was further fractionated to near-purity and peptide masses were determined using matrix-assisted laser desorption/ionization time-of-flight (MALDI-TOF) mass spectrometry (MS) using a Model 4700 Proteomics Analyser (Applied Biosystems, Foster City, CA, USA) with $\alpha$-cyano-4-hydroxycinnamic acid $\left(7 \mathrm{mg} / \mathrm{mL}\right.$ in $50 \% \mathrm{ACN}+5 \%$ formic acid in $\mathrm{H}_{2} \mathrm{O}$ ) as the matrix. Peptide sequences were determined by Edman degradation performed by the Australian Proteome Analysis Facility (Macquarie University, NSW, Australia). Sequence ambiguity was clarified by MS/MS sequencing.

\subsection{Peptide Synthesis}

Peptides (Pme1a, Pme2a and [+K22]Pme2a) were assembled using a Symphony (Protein Technologies Inc., Tuscon, AZ, USA) automated peptide synthesizer on Fmoc-Rink-amide polystyrene resin on $0.1 \mathrm{mmol}$ scale. Amino acid sidechains were protected as $\operatorname{Asn}(\operatorname{Trt}), \operatorname{Arg}(\mathrm{Pbf}), \operatorname{Asp}(\mathrm{OtBu})$, Cys(Trt), Gln(Trt), Glu(OtBu), His(Trt), Lys(Boc), Ser(tBu), Thr(tBu), Trp(Boc) and $\operatorname{Tyr}(t B u)$. Fluorenylmethyloxycarbonyl (Fmoc) removal was achieved using successive treatments with $30 \%$ piperidine/dimethylformamide (DMF) of $1 \mathrm{~min}$ then $3 \mathrm{~min}$. Couplings were performed using 5 equivalents of HCTU/Fmoc-amino acid/N,N-diisopropylethylamine (DIEA) (1:1:1) in DMF, repeated twice (4 min then $8 \mathrm{~min}$ ). Peptide-resins were cleaved using 3\% triisopropylsilane (TIPS) $/ 3 \% \mathrm{H}_{2} \mathrm{O} / \mathrm{TFA}$ for $2 \mathrm{~h}$. Following evaporation of TFA under a stream of nitrogen, peptides were precipitated and washed with cold diethyl ether, dissolved in $50 \%$ ACN $/ 0.1 \%$ TFA $/ \mathrm{H}_{2} \mathrm{O}$ and lyophilised. Crude peptides were purified by preparative RP-HPLC. Oxidative folding was performed in the presence of oxidised and reduced glutathione for 2 day at $4{ }^{\circ} \mathrm{C}$, and the major folded products of correct mass were isolated by preparative RP-HPLC.

\subsection{Calcium Responses in TRPV1-HEK Cells}

HEK cells stably expressing rTRPV1 were plated $48 \mathrm{~h}$ before the assay on 384-well black-walled imaging plates coated with poly D-lysine (ViewPlate-384, Perkin Elmer, Victoria, Australia) at a density of 10,000-15,000 cells/well and loaded with Calcium 4 no-wash dye (Molecular Devices) diluted in PSS and incubated for $30 \mathrm{~min}$ at $37^{\circ} \mathrm{C}$. Capsaicin and Pmela were diluted in PSS with $0.1 \%$ bovine serum albumin (BSA) at the concentrations stated and added using the FLIPR ${ }^{\text {TETRA }}$. Changes in fluorescence were assessed using the FLIPR ${ }^{\text {TETRA }}$ (excitation $470-495 \mathrm{~nm}$, emission 515-575 nm) every $1 \mathrm{~s}$ for $300 \mathrm{~s}$ after the addition of compounds. Fluorescence responses were quantified by the maximum increase in fluorescence calculated using ScreenWorks 3.2.0.14.

\subsection{Electrophysiology}

Whole-cell patch-clamp experiments in $\mathrm{Na}_{\mathrm{V}} 1$.7-HEK cells and $\mathrm{Na}_{\mathrm{V}} 1.8-\mathrm{CHO}$ cells were performed on a QPatch-16 automated electrophysiology platform (Sophion Bioscience, Ballerup, Denmark) as previously described [18]. The extracellular solution contained in $\mathrm{mM}: \mathrm{NaCl} 140, \mathrm{KCl} 4, \mathrm{CaCl}_{2} 2$, $\mathrm{MgCl}_{2}$ 1, HEPES 10 and glucose 10; pH 7.4; osmolarity $305 \mathrm{mOsm}$. The intracellular solution contained in mM: CsF 140, EGTA/CsOH 1/5, HEPES 10 and $\mathrm{NaCl} 10$; pH 7.3 with $\mathrm{CsOH}$; osmolarity 320 mOsm. Concentration-response curves were acquired using a holding potential of $-90 \mathrm{mV}$ and a $50 \mathrm{~ms}$ pulse to $-20 \mathrm{mV}$ (for $\mathrm{Na}_{V} 1.7$ ) or $+10 \mathrm{mV}$ (for $\mathrm{Na}_{V} 1.8$ ) every $20 \mathrm{~s}(0.05 \mathrm{~Hz}$ ). Peptides were diluted in extracellular solution with $0.1 \%$ BSA and each peptide concentration was incubated for $5 \mathrm{~min}$. Peak current was normalized to buffer control. The time constant of fast inactivation $(\tau)$ was computed by fitting the current decay traces with a single exponential function using the QPatch Assay Software 
5.6 (Sophion). $I-V$ curves were obtained with a holding potential of $-90 \mathrm{mV}$ followed by a series of $500 \mathrm{~ms}$ step pulses that ranged from -110 to $+55 \mathrm{mV}$ in $5 \mathrm{mV}$ increments (repetition interval $5 \mathrm{~s}$ ) before and after $5 \mathrm{~min}$ incubation or Pme1a $(1 \mu \mathrm{M})$. Conductance-voltage curves were obtained by calculating the conductance $(G)$ at each voltage $(V)$ using the equation $G=I /\left(V-V_{\text {rev }}\right)$, where $V_{\text {rev }}$ is the reversal potential and were fitted with a Boltzmann equation.

\subsection{Data Analysis}

Data were plotted and analysed using GraphPad Prism, version 8.2.0. For concentration-response curves, a four-parameter Hill equation with variable Hill coefficient was fitted to the data. Data are presented as the mean \pm SEM.

\section{Results}

\subsection{Isolation of the Novel Spider Venom Peptides $\mu$-TRTX-Pme1a and $\mu / \delta$-TRTX-Pme2a from P. metallica}

Crude venom isolated from P. metallica (Figure 1A) inhibited deltamethrin-induced membrane potential changes in $\mathrm{CHO}$ cells stably expressing $\mathrm{hNa}_{\mathrm{V}} 1.8$, with activity guided fractionation isolating this activity to a single peak eluting at $\sim 35 \%$ solvent B (Figure 1A). Matrix-assisted laser desorption/ionization time-of-flight mass spectrometry (MALDI-TOF MS) indicated that this fraction was dominated by two masses $(\mathrm{M}+\mathrm{H})^{+}$of $3911.6 \mathrm{~m} / \mathrm{z}$ and $3808.5 \mathrm{~m} / \mathrm{z}$ (Figure 1B). N-terminal sequencing revealed two novel 35 and 33 residue peptides that we named $\mu$-TRTX-Pmela (hereafter Pme1a) and $\mu / \delta$-TRTX-Pme2a (hereafter Pme2a) based on the rational nomenclature for peptide toxins (Figure 1C) [19]. The calculated masses and observed masses differed by $-1 \mathrm{Da}$, indicating both Pme1a and Pme2a have an amidated C-terminus. Synthetic Pme1a and Pme2a with C-terminal amidation were used for all further experiments.

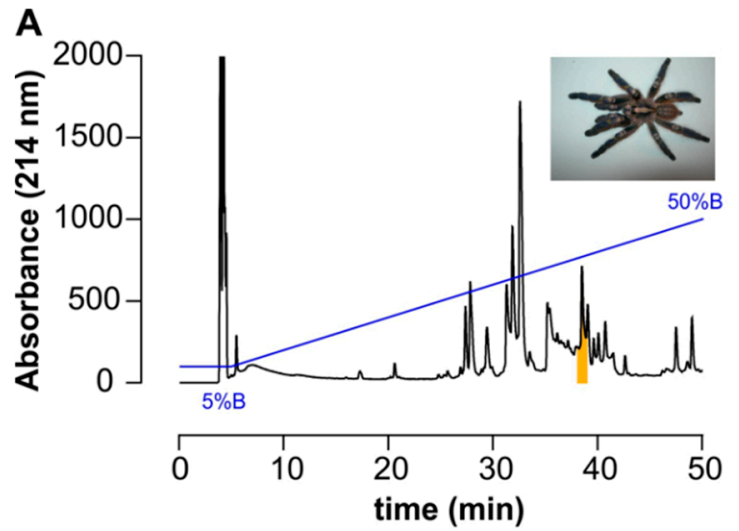

C Toxin name

\section{$\mu$-TRTX-Pme1a} $\mu / \delta$-TRTX-Pme2a
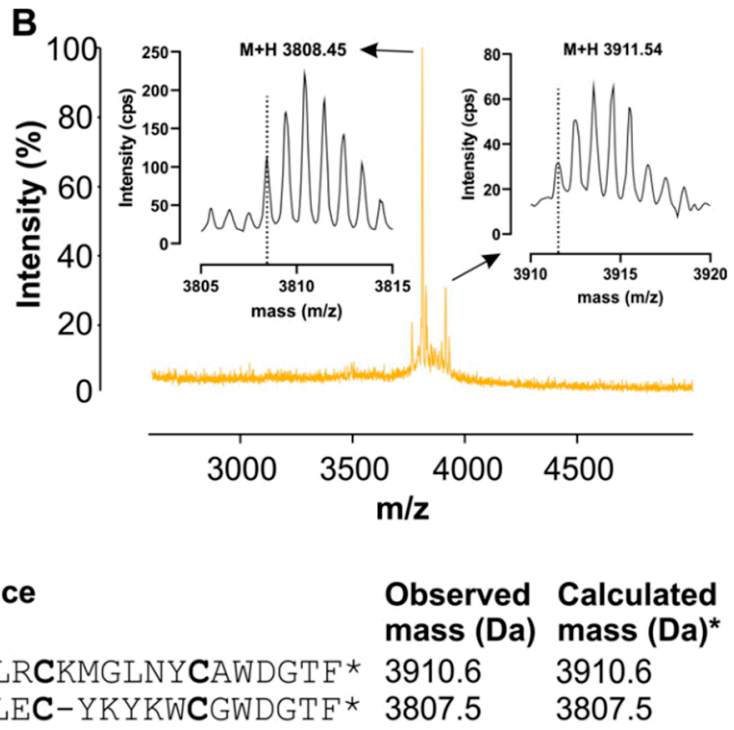

Figure 1. Isolation of novel spider peptides $\mu$-TRTX-Pme1a and $\mu / \delta$-TRTX-Pme2a from the venom of P. metallica. (A) Chromatogram resulting from fractionation of the crude venom using RP-HPLC. Blue line indicates gradient of solvent $\mathrm{B}$. Colour indicates the active peak that was further purified using activity guided fraction. (B) MALDI-TOF MS spectrum showing the $\mathrm{M}+\mathrm{H}^{+}$ions for the dominant masses present in the active peak. (C) Sequences of $\mu$-TRTX-Pme1a and $\delta$-TRTX-Pme2a identified by N-terminal sequencing and their observed (uncharged) and calculated (uncharged) monoisotopic masses. The calculated mass was -1 Da due to the amidated C-terminus (as indicated by *). 


\subsection{Pharmacological Activity of Pme1a}

Alignment of Pme1a to peptide sequences from the Universal Protein Resource (www.uniprot.org) revealed that the peptide shares high sequence homology $(56 \%-80 \%)$ with the vanillotoxins (Figure 2), a family of peptides from Psalmopoeus cambridgei that activate TRPV1 with $\mathrm{EC}_{50}$ s ranging between 0.32 and $12 \mu \mathrm{M}$ [20]. We therefore tested the activity of Pme1a on TRPV1 heterologously expressed in HEK293 cells. In comparison to the TRPV1 activator capsaicin (EC $5083 \mathrm{nM}$ ), Pme1a (up to $30 \mu \mathrm{M})$ had no activity on TRPV1, suggesting that amino acid residue(s) crucial for TRPV1 activity are missing from this peptide (Figure $3 \mathrm{~A}$ ). As Pmela was discovered using a $\mathrm{Na}_{\mathrm{V}}$ channel screen, we next characterised its activity on $\mathrm{Na}_{V}$ channels using automated whole-cell patch-clamp electrophysiology.

\begin{tabular}{|c|c|c|}
\hline Name & Sequence & Target \\
\hline$\mu$-TRTX-Pme1a & - - - GGC-RYFLGGCSEHSDCCEHLRCKMGLNYCAWDGTF - * & $\mathrm{Na}_{V}$ \\
\hline Pf32 & - - - -AGC-RYFLGGCTEHSDCCEHLSCKMGLNYCAWDGTF- & Unknown \\
\hline Pf29 & - - - - - CSRYFLGGCTEHSDCCEHLSCKMGLNYCAWDGTF - & Unknown \\
\hline T-TRTX-Pc1b & - - - -GAC-RWFLGGCKSTSDCCEHLSCKMGLDYCAWDGTF - * & TRPV1 \\
\hline$\delta$-TRTX-Cg2a & - - - - EC-TKFLGGCSEDSECCPHLGCKDVLYYCAWDGTF - * & $\mathrm{Na}_{V}$ \\
\hline T/K-TRTX-Pc1a & - - - -SEC-RWFMGGCDSTLDCCKHLSCKMGLYYCAWDGTF - * & TRPV $1 / K_{V} 2.1$ \\
\hline K-TRTX-Cg1a & - - - - EC-RKMFGGCSVDSDCCAHLGCKPTLKYCAWDGTF - * & $\mathrm{K}_{\mathrm{V}} 2.1$ \\
\hline$\delta$-TRTX-Hm1a & - - - - EC-RYLFGGCSSTSDCCKHLSCRSDWKYCAWDGTFS & $\mathrm{Na}_{\vee} 1.1$ \\
\hline$\mu-T R T X-P n 3 a$ & - - - - DC-RYMFGDCEKDEDCCKHLGCKRKMKYCAWDFTFT & $\mathrm{Na}_{\mathrm{V}} 1.7$ \\
\hline T-TRTX-Pc1c & - - - - EC-RWYLGGCKEDSECCEHLQCHSYWEWCLWDGSF - * & TRPV1 \\
\hline$\beta$-TRTX-Cm2a & GVDKEGC-RKLLGGCTIDDDCCPHLGCNKKYWHCGWDGTF - * & $\mathrm{Na}_{\vee} 1.5$ \\
\hline$\mu / \delta-T R T X-P m e 2 a$ & - - - - GC-TKFMGSCKTDADCCEHLEC-YKYKWCGWDGTF - * & $\mathrm{Na}_{V}$ \\
\hline
\end{tabular}

Figure 2. Sequence alignment of Pme1a and Pme2a. Sequence alignment of Pme1a and Pme2a with \% sequence identity (to Pme1a) to selected mature spider peptides with a known target from Universal Protein Resource (www.uniprot.org) and two sequences identified from the venom gland of the related species $P$. formosa with unknown activity. Cysteine residues are shown in bold and * indicates amidated C-terminus. Pme1a and Pme2a align to spider peptides belonging to NaSpTx2 family 2. 

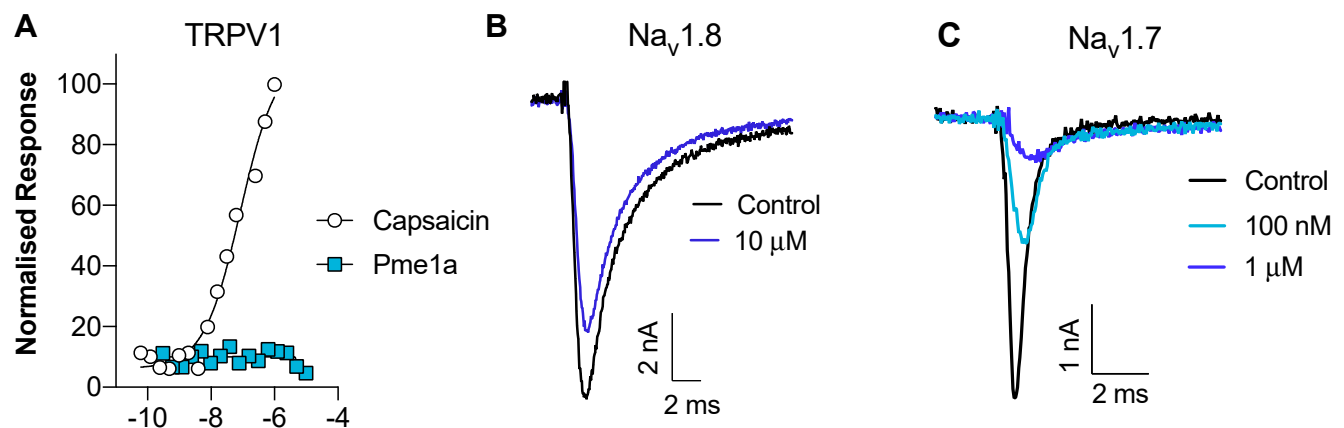

Log [Conc] M

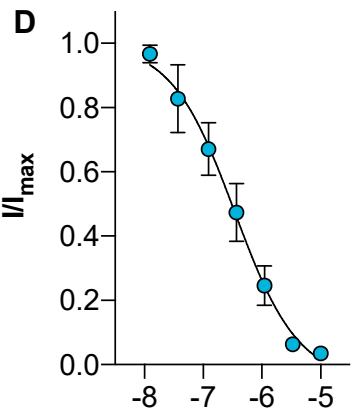

Log [Pme1a] M
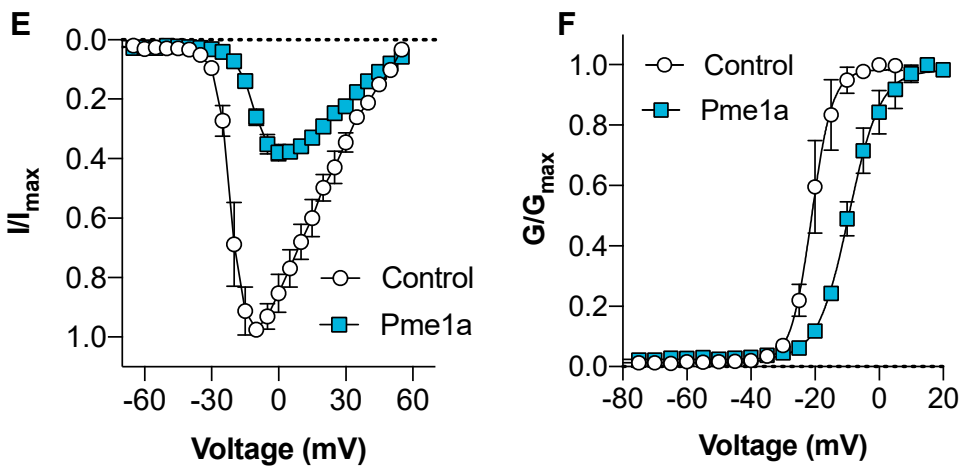

Figure 3. Activity of synthetic Pme1a on TRPV1, $\mathrm{Na}_{V} 1.8$ and $\mathrm{Na}_{V}$ 1.7. (A) Concentration-response curves for capsaicin and Pme1a at rTRPV1 assessed by calcium dye. Data are presented as the mean \pm SEM, with $n=3-5$ wells per data point. (B) Representative $\mathrm{hNa}_{\mathrm{V}} 1.8$ current trace before (black) and after addition of Pme1a (blue). Currents were elicited by a $50 \mathrm{~ms}$ pulse to $+10 \mathrm{mV}$ from a holding potential of $-90 \mathrm{mV}$. (C) Representative $\mathrm{hNa}_{\mathrm{V}} 1.7$ current trace before (black) and after addition of Pme1a (blue). Currents were elicited by a $50 \mathrm{~ms}$ pulse to $-20 \mathrm{mV}$ from a holding potential of $-90 \mathrm{mV}$. (D) Concentration-response curve for Pme1a at hNa $1.7\left(\mathrm{IC}_{50} 334 \pm 114 \mathrm{nM}\right)$. (E) Current-voltage relationship before (white circles) and after addition of $1 \mu \mathrm{M}$ Pmela (blue squares). (F) Conductance-voltage curve before (white circles) and after addition of $1 \mu \mathrm{M}$ Pme1a (blue squares). Pmela shifted the $\mathrm{V}_{1 / 2}$ of voltage dependence of activation by $+11.6 \mathrm{mV}$. Data are presented as the mean \pm SEM, with $n=3-6$ cells per data point.

Despite being isolated as an inhibitor of $\mathrm{Na}_{\mathrm{V}} 1.8$ using a fluorescent screen, Pme1a only had modest activity on Nav1.8, inhibiting $21 \pm 2 \%$ of the peak current at a concentration of $10 \mu \mathrm{M}$ (Figure 3B). In contrast, Pmela was more potent at $\mathrm{Na}_{\mathrm{V}} 1.7$, inhibiting peak current with an $\mathrm{IC}_{50}$ of $334 \pm 114 \mathrm{nM}$ (Figure 3C,D). Activity at other $\mathrm{Na}_{\mathrm{V}}$ channel subtypes is not unexpected, given the high-sequence homology between $\mathrm{Na}_{\mathrm{V}}$ subtypes [12]. To examine the mechanism of channel block, we next assessed the effect of Pmela on the voltage-current relationship at $\mathrm{Na}_{V} 1.7$ (Figure 3E). Pmela $(1 \mu \mathrm{M})$ shifted the voltage dependence of activation at $\mathrm{Na}_{\mathrm{V}} 1.7$ to more depolarised membrane potentials ( $\mathrm{V}_{1 / 2}$ activation: $\Delta=+11.6 \mathrm{mV}$ ), confirming it binds to the voltage-sensing domain(s) to modify channel gating (Figure $3 \mathrm{~F}$ ).

\subsection{Pharmacological Activity of Pme2a}

Alignment of Pme2a to peptide sequences from the Universal Protein Resource (www.uniprot.org) revealed that the peptide shares sequence homology $(<65 \%)$ to Pmela and other peptides with activity at $\mathrm{Na}_{\mathrm{V}}$ channels (Figure 2). Similar to Pme1a, Pme2a had no activity at TRPV1 (data not shown), and only modest activity at Nav1.8, with the highest concentration tested $(10 \mu \mathrm{M})$ inhibiting $22 \pm 4 \%$ of peak current (Figure 4A). Pme2a also had modest activity at $\mathrm{Na}_{\mathrm{V}} 1.7$, concentration-dependently delaying-fast inactivation, albeit not potently, with an estimated $\mathrm{EC}_{50}>10 \mu \mathrm{M}$ (Figure 4B,C). Due to low potency at $\mathrm{Na}_{\mathrm{V}} 1.7$, no further pharmacological characterisation was performed. 


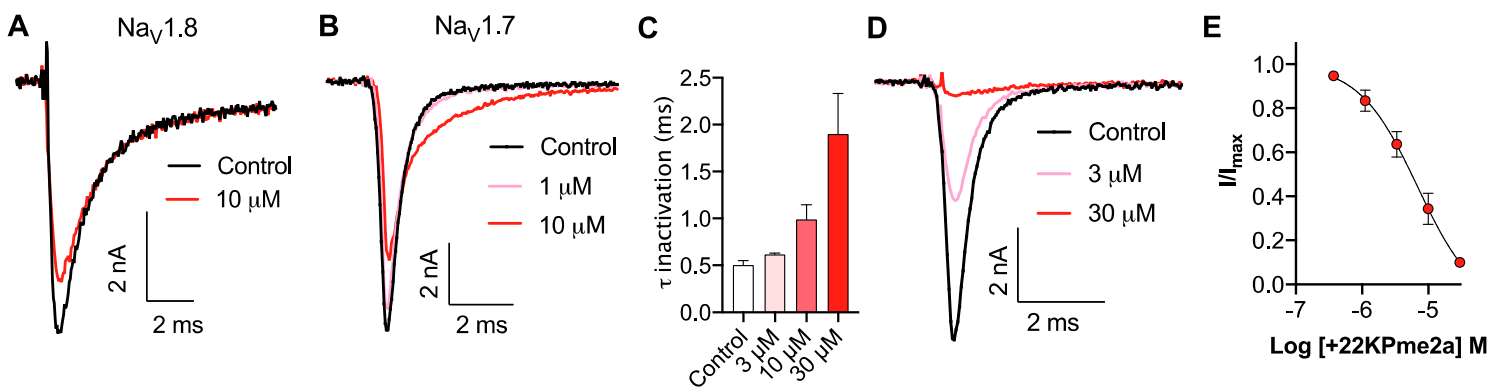

Figure 4. Activity of synthetic Pme2a and [+22K]Pme2a on $\mathrm{Na}_{\mathrm{V}} 1.8$ and $\mathrm{Na}_{\mathrm{V}} 1.7$. (A) Representative $\mathrm{hNa}_{\mathrm{V}} 1.8$ current trace before (black) and after addition of Pme2a (red). Currents were elicited by a $50 \mathrm{~ms}$ pulse to $+10 \mathrm{mV}$ from a holding potential of $-90 \mathrm{mV}$. (B) Representative $\mathrm{hNa}_{\mathrm{V}} 1.7$ current trace before (black) and after addition of Pme2a (red). Currents were elicited by a $50 \mathrm{~ms}$ pulse to $-20 \mathrm{mV}$ from a holding potential of $-90 \mathrm{mV}$. (C) Pme2a concentration-dependently increases the time constant of fast inactivation $(\tau)$ at $h N a_{V} 1.7$. (D) Representative $\mathrm{hNa}_{\mathrm{V}} 1.7$ current trace before (black) and after addition of $[+22 \mathrm{~K}] \mathrm{Pme} 2 \mathrm{a}$ (red). Currents were elicited by a $50 \mathrm{~ms}$ pulse to $-20 \mathrm{mV}$ from a holding potential of $-90 \mathrm{mV}$. (E) Concentration-response curve for [+22K]Pme2a at hNa $1.7\left(\mathrm{IC}_{50} 5.6 \pm 1.1\right.$ $\mu \mathrm{M})$. Data are presented as the mean \pm SEM, with $n=4$ cells per data point.

Sequence alignment revealed that loop 4 of Pme2a is one amino acid residue shorter compared to others in the family, and peptides with activity on TTX-sensitive $\mathrm{Na}_{V}$ channels generally contain a positively charged amino acid at the equivalent position, most often a lysine (Figure 2). We therefore synthesised a [+22K]Pme2a mutant and assessed how the addition of a lysine affected activity at $\mathrm{Na}_{V}$ 1.7. [+22K]Pme2a concentration-dependently inhibited $\mathrm{Na}_{\mathrm{V}} 1.7$ peak current, without the delay in fast activation seen with the native peptide, with a more potent $\mathrm{IC}_{50}$ of $5.6 \pm 1.1 \mu \mathrm{M}$ (Figure $4 \mathrm{D}, \mathrm{E}$ ).

\section{Discussion}

Here, we describe the isolation and $\mathrm{Na}_{V}$ activity of two novel spider venom-derived peptides, which are the first peptides to be isolated and functionally characterised from the venom of the species P. metallica, as well as the entire Poecilotheria genus [21]. A transcriptome and proteome from the venom gland of the related species $P$. formosa identified two related, but not identical peptide sequences (Pf29 and Pf32) [22], indicating that the entire Poecilotheria genus is likely to be a rich source of novel $\mathrm{Na}_{\mathrm{V}}$ modulators (Figure 2). Indeed, crude venom from several species of the Poecilotheria genus, including P. metallica, has previously been shown to modulate $\mathrm{Na}_{\mathrm{V}} 1.7$ [23], consistent with activity of Pme1a and Pme2a at both $\mathrm{Na}_{\mathrm{V}} 1.7$ and $\mathrm{Na}_{\mathrm{V}} 1.8$ described here. The two peptides isolated here were only moderately potent at $\mathrm{Na}_{\mathrm{V}} 1.7$ and $\mathrm{Na}_{\mathrm{V}} 1.8$, indicating that there may still be additional peptides in the crude venom with more potent activity.

Specifically, both Pme1a and Pme2a align with NaSpTx family 2, which is a large family of spider venom peptides that have promiscuous activity on $\mathrm{Na}_{\mathrm{V}}, \mathrm{K}_{\mathrm{V}}$ and $\mathrm{Ca}_{\mathrm{V}}$ channels [24]. Interestingly, this family also contains members that have high selectivity for $\mathrm{Na}_{V}$ channels of therapeutic interest, including the $\mathrm{Na}_{V} 1.7$ inhibitor $\mu$-TRTX-Pn3a and the $\mathrm{Na}_{V} 1.1$ activator $\delta$-TRTX-Hm1a. However, little is known about the structure-activity relationships that define the pharmacology of this family $[25,26]$. Here, we describe the importance of a lysine $(\mathrm{K})$ at position "22" (using Pme2a numbering) for $\mathrm{Na}$ channel activity. The presence of the positively charged amino acid residue lysine is often important for facilitating membrane interactions in venom-based peptides [18,27]. Addition of K22 altered the pharmacology of Pme2a, converting the native peptide from being a $\mathrm{Na}_{\mathrm{V}} 1.7$ channel activator to a more potent $\mathrm{Na}_{\mathrm{V}} 1.7$ channel inhibitor. This is a significant finding, indicating that the amino acid residue(s) present at or around this site can dictate whether family 2 peptides function as $\mathrm{Na}_{\mathrm{V}}$ activators or inhibitors. It is also possible that extending loop 4 of Pme2a by one amino acid residue contributed to the change in activity by slightly altering the overall structure of the peptide. Future 
studies elucidating the full $\mathrm{Na}_{\mathrm{V}}$ selectivity of Pme1a and Pme2a will further define which amino acid residues are important for $\mathrm{Na}_{V}$ channel potency and subtype selectivity.

In conclusion, we have identified two novel spider venom-derived peptides that modulate $\mathrm{Na}_{\mathrm{V}}$ channels. Results from this study provide structure-activity relationship information that may guide the future rational design of spider venom-derived peptides with improved activity and selectivity at $\mathrm{Na}_{\mathrm{V}}$ channels.

Author Contributions: K.Y., J.R.D., Z.D. and I.V. conceived of and designed the experiments. K.Y, J.R.D., Z.D., A.-H.J., V.H. and I.V. performed the experiments. K.Y. and J.R.D. analysed the data. G.F.K. and P.F.A. contributed reagents/materials/analysis tools. J.R.D., V.H. and I.V. wrote the paper. All authors have read and agreed to the published version of the manuscript.

Funding: This work was supported by an Australian National Health and Medical Research Council (NMHRC) Career Development Fellowship (APP1162503, I.V.), an NHMRC Early Career Fellowship (APP1139961, J.R.D.), NHMRC Principal Research Fellowships (APP1080593, P.F.A.; APP1136889 G.F.K.) and a University of Queensland Research Scholarship (K.Y.).

Acknowledgments: This research was facilitated by access to the Australian Proteome Analysis Facility, which is supported under the Australian Government's National Collaborative Research Infrastructure Strategy. We thank the members of the Deutsche Arachnologische Gesellschaft (DeArGe) for providing P. metallica spiders for milking, particularly Henrik Krehenwinkel, Arnd Schlosser, Ralf Lühr, Michelle Lüscher, Bastian Rast and Patrick Meyer.

Conflicts of Interest: The authors declare no conflict of interest.

\section{References}

1. Catterall, W.A.; Goldin, A.L.; Waxman, S.G. International Union of Pharmacology. XLVII. Nomenclature and structure-function relationships of voltage-gated sodium channels. Pharmacol. Rev. 2005, 57, 397-409. [CrossRef] [PubMed]

2. Shields, S.D.; Ahn, H.S.; Yang, Y.; Han, C.; Seal, R.P.; Wood, J.N.; Waxman, S.G.; Dib-Hajj, S.D. Nav1.8 expression is not restricted to nociceptors in mouse peripheral nervous system. Pain 2012, 153, 2017-2030. [CrossRef] [PubMed]

3. Djouhri, L.; Fang, X.; Okuse, K.; Wood, J.N.; Berry, C.M.; Lawson, S.N. The TTX-resistant sodium channel Nav1.8 (SNS/PN3): Expression and correlation with membrane properties in rat nociceptive primary afferent neurons. J. Physiol. 2003, 550, 739-752. [CrossRef] [PubMed]

4. Black, J.A.; Frezel, N.; Dib-Hajj, S.D.; Waxman, S.G. Expression of $\mathrm{Na}_{\mathrm{V}} 1.7$ in DRG neurons extends from peripheral terminals in the skin to central preterminal branches and terminals in the dorsal horn. Mol. Pain 2012, 8, 82. [CrossRef] [PubMed]

5. Faber, C.G.; Lauria, G.; Merkies, I.S.; Cheng, X.; Han, C.; Ahn, H.S.; Persson, A.K.; Hoeijmakers, J.G.; Gerrits, M.M.; Pierro, T.; et al. Gain-of-function Nav1.8 mutations in painful neuropathy. Proc. Natl. Acad. Sci. USA 2012, 109, 19444-19449. [CrossRef] [PubMed]

6. Xiao, Y.; Barbosa, C.; Pei, Z.; Xie, W.; Strong, J.A.; Zhang, J.M.; Cummins, T.R. Increased resurgent sodium currents in Nav1.8 contribute to nociceptive sensory neuron hyperexcitability associated with peripheral neuropathies. J. Neurosci. 2019, 39, 1539-1550. [CrossRef]

7. Waxman, S.G.; Dib-Hajj, S.D. The two sides of NaV1.7: Painful and painless channelopathies. Neuron 2019, 101, 765-767. [CrossRef]

8. Abrahamsen, B.; Zhao, J.; Asante, C.O.; Cendan, C.M.; Marsh, S.; Martinez-Barbera, J.P.; Nassar, M.A.; Dickenson, A.H.; Wood, J.N. The cell and molecular basis of mechanical, cold, and inflammatory pain. Science 2008, 321, 702-705. [CrossRef]

9. Gingras, J.; Smith, S.; Matson, D.J.; Johnson, D.; Nye, K.; Couture, L.; Feric, E.; Yin, R.; Moyer, B.D.; Peterson, M.L.; et al. Global Nav1.7 knockout mice recapitulate the phenotype of human congenital indifference to pain. PLoS ONE 2014, 9, e105895. [CrossRef]

10. Rogart, R.B.; Cribbs, L.L.; Muglia, L.K.; Kephart, D.D.; Kaiser, M.W. Molecular cloning of a putative tetrodotoxin-resistant rat heart $\mathrm{Na}^{+}$channel isoform. Proc. Natl. Acad. Sci. USA 1989, 86, 8170-8174. [CrossRef] 
11. Whitaker, W.R.; Faull, R.L.; Waldvogel, H.J.; Plumpton, C.J.; Emson, P.C.; Clare, J.J. Comparative distribution of voltage-gated sodium channel proteins in human brain. Brain Res. Mol. Brain Res. 2001, 88, 37-53. [CrossRef]

12. Vetter, I.; Deuis, J.R.; Mueller, A.; Israel, M.R.; Starobova, H.; Zhang, A.; Rash, L.D.; Mobli, M. Nav1.7 as a pain target-From gene to pharmacology. Pharmacol. Ther. 2017, 172, 73-100. [CrossRef] [PubMed]

13. Israel, M.R.; Morgan, M.; Tay, B.; Deuis, J.R. Toxins as tools: Fingerprinting neuronal pharmacology. Neurosci. Lett. 2018, 679, 4-14. [CrossRef] [PubMed]

14. Israel, M.R.; Tay, B.; Deuis, J.R.; Vetter, I. Sodium channels and venom peptide pharmacology. Adv. Pharmacol. 2017, 79, 67-116. [CrossRef] [PubMed]

15. Gilchrist, J.; Bosmans, F. Animal toxins can alter the function of $\mathrm{Na}_{\mathrm{V}} 1.8$ and $\mathrm{Na}_{\mathrm{V}}$ 1.9. Toxins (Basel) 2012, 4, 620-632. [CrossRef]

16. Vetter, I.; Wyse, B.D.; Monteith, G.R.; Roberts-Thomson, S.J.; Cabot, P.J. The $\mu$ opioid agonist morphine modulates potentiation of capsaicin-evoked TRPV1 responses through a cyclic AMP-dependent protein kinase a pathway. Mol. Pain 2006, 2, 22. [CrossRef]

17. Herzig, V.; Hodgson, W.C. Neurotoxic and insecticidal properties of venom from the Australian theraphosid spider Selenotholus foelschei. Neurotoxicology 2008, 29, 471-475. [CrossRef]

18. Deuis, J.R.; Dekan, Z.; Inserra, M.C.; Lee, T.H.; Aguilar, M.I.; Craik, D.J.; Lewis, R.J.; Alewood, P.F.; Mobli, M.; Schroeder, C.I.; et al. Development of a $\mu$ O-Conotoxin analogue with improved lipid membrane interactions and potency for the analgesic sodium channel Na 1 1.8. J. Biol. Chem. 2016, 291, 11829-11842. [CrossRef]

19. King, G.F.; Gentz, M.C.; Escoubas, P.; Nicholson, G.M. A rational nomenclature for naming peptide toxins from spiders and other venomous animals. Toxicon 2008, 52, 264-276. [CrossRef]

20. Siemens, J.; Zhou, S.; Piskorowski, R.; Nikai, T.; Lumpkin, E.A.; Basbaum, A.I.; King, D.; Julius, D. Spider toxins activate the capsaicin receptor to produce inflammatory pain. Nature 2006, 444, 208-212. [CrossRef]

21. Pineda, S.S.; Chaumeil, P.A.; Kunert, A.; Kaas, Q.; Thang, M.W.C.; Le, L.; Nuhn, M.; Herzig, V.; Saez, N.J.; Cristofori-Armstrong, B.; et al. ArachnoServer 3.0: An online resource for automated discovery, analysis and annotation of spider toxins. Bioinformatics 2018, 34, 1074-1076. [CrossRef] [PubMed]

22. Oldrati, V.; Koua, D.; Allard, P.M.; Hulo, N.; Arrell, M.; Nentwig, W.; Lisacek, F.; Wolfender, J.L.; Kuhn-Nentwig, L.; Stocklin, R. Peptidomic and transcriptomic profiling of four distinct spider venoms. PLoS ONE 2017, 12, e0172966. [CrossRef] [PubMed]

23. Klint, J.K.; Smith, J.J.; Vetter, I.; Rupasinghe, D.B.; Er, S.Y.; Senff, S.; Herzig, V.; Mobli, M.; Lewis, R.J.; Bosmans, F.; et al. Seven novel modulators of the analgesic target $\mathrm{Na}_{\mathrm{V}} 1.7$ uncovered using a high-throughput venom-based discovery approach. Br. J. Pharmacol. 2015, 172, 2445-2458. [CrossRef] [PubMed]

24. Klint, J.K.; Senff, S.; Rupasinghe, D.B.; Er, S.Y.; Herzig, V.; Nicholson, G.M.; King, G.F. Spider-venom peptides that target voltage-gated sodium channels: Pharmacological tools and potential therapeutic leads. Toxicon 2012, 60, 478-491. [CrossRef]

25. Deuis, J.R.; Dekan, Z.; Wingerd, J.S.; Smith, J.J.; Munasinghe, N.R.; Bhola, R.F.; Imlach, W.L.; Herzig, V.; Armstrong, D.A.; Rosengren, K.J.; et al. Pharmacological characterisation of the highly Nav1.7 selective spider venom peptide Pn3a. Sci. Rep. 2017, 7, 40883. [CrossRef]

26. Osteen, J.D.; Herzig, V.; Gilchrist, J.; Emrick, J.J.; Zhang, C.; Wang, X.; Castro, J.; Garcia-Caraballo, S.; Grundy, L.; Rychkov, G.Y.; et al. Selective spider toxins reveal a role for the $\mathrm{Na}_{\mathrm{V}} 1.1$ channel in mechanical pain. Nature 2016, 534, 494-499. [CrossRef]

27. Lin King, J.V.; Emrick, J.J.; Kelly, M.J.S.; Herzig, V.; King, G.F.; Medzihradszky, K.F.; Julius, D. A Cell-penetrating scorpion toxin enables mode-specific modulation of TRPA1 and pain. Cell 2019, 178, 1362-1374. [CrossRef]

(C) 2020 by the authors. Licensee MDPI, Basel, Switzerland. This article is an open access article distributed under the terms and conditions of the Creative Commons Attribution (CC BY) license (http://creativecommons.org/licenses/by/4.0/). 